\title{
PPT MELALUI CLASSROOM UNTUK MENINGKATKAN MOTIVASI BELAJAR PESERTA DIDIK DI TENGAH PANDEMI COVID - 19 PADA SMA N CANDIROTO, KABUPATEN TEMANGGUNG
}

\author{
FARIDA ARIYANI \\ SMA Negeri Candiroto Temanggung Jawa Tengah \\ Email : faridaariyani6646@gmail.com
}

\begin{abstract}
ABSTRAK
Classroom sebagai salah satu jenis dari sekian banyak jenis learning management sytem banyak dipilih sekolah sebagai media pembelajaran dalam masa pandemi ini. Clasroom memiliki berbagai keunggulan yang dapat menunjang proses berlangsungnya pembelajaran jarak jauh. Keutamaan classroom seperti related dengan perkembangan teknologi, praktis dan mudah diakses, proses pembelajaran menjadi lebih efisien, melatih kemandirian bagi murid, terdapat fitur-fitur tambahan yang mempermudah penugasan atau penyimpanan dokumen, tidak terkendala jarak, dan menjadi media yang sangat praktis dalam bertukar pikiran atau menjadi wadah diskusi. Di SMA Negeri 1 Candiroto nyata sekali perbedaan efektifitas penggunaan classroom dengan media sebelumnya seperti penggunaan gruop wa dan juga telegram. Dengan calssroom permasalahan yang timbul dalam pembelajaran daring seperti keaktifan siswa, diskusi yang kurang interaktif dan juga pengerjaan tugas yang tertunda menjadi sangat berkurang. Jika sebelumnya guru menggunakan vidio call, voice note dengan banyak siswa dengan pemanfaatan google meet pada fitur classrroom mempermudah guru untuk berinteraksi dengan siswa, melihat keaktifan siswa dan juga melakukan absensi langsung. Penelitian ini bertujuan untuk mengetahui peningkatan motivasi belajar peserta didik dalam pembelajaran online. Penelitian ini merupakan penelitian kualitatif dengan tehnik analisis diskriptif . Dari data sekolah SMA Negeri 1 Candiroto dapat terlihat perubahan yang signifikan tingkat permasalahan yang timbul saat sebelum dan sesudah penggunaan classroom. Sebelum penggunaan media classroom muncul jumlah kasus sebanyak 99 siswa dilihat dari keaktifan pada classroom guru mata pelajaran, absensi harian dan juga ketepatan pengumpulan tugas. Setelah penggunaan classroom menurun hanya sekitar 34 siswa yang mempunyai permasalahan seputar pembelajaran daring. Dari data tersebut penulis merasa bahwa penggnaan media classroom sangat efektif menunjang pembelajaran daring.
\end{abstract}

Kata kunci : Pembelajaran daring, motivasi belajar, google classroom,powerpoint

\section{PENDAHULUAN}

Lembaga pendidikan melakukan inovasi dalam proses pembelajaran. Salah satu bentuk inovasi tersebut ialah dengan melakukan pembelajaran secara online atau daring (dalam jaringan). Pembelajaran Daring bertujuan memberikan layanan pembelajaran bermutu dalam jaringan (daring) yang bersifat masif dan terbuka untuk menjangkau peminat yang lebih banyak dan lebih luas (Sofyana \& Rozaq, 2019).Walaupun dikatakan oleh ( Bilfaqih \& Qamruddin, 2015 ) pembelajaran daring mampu memberikan layanan yang menarik dan efekti ( f, tetap saja dalam pelaksanaanya memiliki tantangan sendiri. Harjanto dan Sumunar (2018)menyatakan bahwa pembelajaran daring ini merupakan proses transformasi pendidikan konvensional ke dalam bentuk digital sehingga memiliki tantangan dan peluang tersendiri. Oleh karena itu, adanya hambatan yang terdapat dalam proses pembelajaran daring harus dapat ditemukan solusinya.

Google classroom merupakan aplikasi berupa learning system management yang disediakan google dan bisa dihubungkan dengan email, sehingga mudah untuk diakses (Suhada dkk., 2020).Google classroom dianggap sebagai salah satu platform terbaik di luar sana untuk meningkatkan alur kerja dan termasuk layanan web gratis, yang dikembangkan oleh google untuk sekolah, yang bertujuan untuk menyederhanakan, membuat, mendistribusikan, dan menilai tugas dengan tanpa kertas (Santosa, Negara, and Samsul Bahri 2020).Dengan Google 


\section{EDUTECH : Jurnal Inovasi Pendidikan Berbantuan Teknologi \\ Vol. 1 No. 2 Agustus 2021, e-ISSN : 2797-0140 | p-ISSN : 2797-0590}

Classroom diharapkan menjadi solusi untuk mengatasi kesulitan dalam melaksanakan pembelajaran daring dan diharapkan dapat mempertahankan kelas tetap aktif meskipun sekolah telah ditutup walaupun pendidik dan peserta didik tidak dapat bertemu secara langsung namun proses pembelajaran dapat berjalan dengan lancar. Guru dan pendidik sebagai elemen penting dalam pengajaran diharuskan melakukan migrasi besar- besaran yang belum pernah terjadi sebelumya dari pendidikan tatap muka tradisional ke pendidikan online atau pendidikan jarak jauh (Bao, 2020; Basilaia \& Kvavadze, 2020).

Pembelajaran online dapat memanfaatkan platform berupa aplikasi, website, jejaring social maupun learning management system (Gunawan et al., 2020).Pemanfaatan media pembelajaran dengan memanfaatkan program aplikasi Microsof Powerpoint dilakukan dengan mengemas materi ajar secara menarik, singkat, padat dan efektif. Dengan media tersebut diharapkan siswa menjadi termotivasi untuk belajar. Pembelajaran disesuaikan dengan situasi dan kondisi peserta didik, serta karakteristik dari setiap indikator dan kompetensi yang hendak dicapai pada setiap mata pelajaran. Untuk mencapai ini semua siswa tidak bisa dibiarkan sendiri karena siswa sangat membutuhkan motivasi. Motivasi dapat diperoleh siswa dari berbagai arah antara lain dari orang tua, masyarakat, guru dan media, baik itu media cetak maupun media elektronik.

Motivasi belajar adalah keseluruhan data penggerak psikis dalam diri peserta didik yang menimbulkan kegiatan belajar(Syaripah, 2016).Motivasi belajar sangat berperan penting dalam mencapai tujuan belajar peserta didik, khususnya pada pelajaran yang tergolong sulit dan membutuhkan analisis yang tinggi (Fadillah and Baist 2017).Motivasi juga berperan penting dalam proses belajar mengajar baik bagi guru maupun siswa. Bagi guru mengetahui motivasi belajar dari siswa sangat diperlukan guna memelihara dan meningkatkan semangat belajar siswa.Bagi siswa motivasi belajar dapat menumbuhkan semangat belajar sehingga siswa terdorong untuk melakukan perbuatan belajar. Saat ini, banyak siswa yang kurang termotivasi untuk belajar. Hal tersebut dapat di lihat dari sikap siswa yang acuh terhadap proses pembelajaran, tidak memperhatikan guru ketika menjelaskan materi serta tidak mengerjakan tugas yang diberikan oleh guru.

Secara teoritis motivasi mempunyai pengaruh positif terhadap hasil belajar siswa, artinya tinggi rendahnya motivasi siswa akan diikuti oleh tinggi-rendahnya hasil belajar. Hasil belajar siswa yang baik diperoleh melalui proses belajar yang baik. Problematika saat ini masih banyak peserta didik yangkurang berminat dan tertarik terkait dengan pembelajaran kalau hanya berkomunikasi menggunakan media chat saja, hal ini dapat di lihat pada nilai tugas ataupun ulangan yang di berikan oleh guru tidak menunjukkan hasil yang rendah serta tingkat kehadiran peserta didik yang masih kurang. Sehingga penting bagi guru untuk terus melakukan refleksi dan evaluasi berkaitan dengan masalah pembelajaran yang dihadapi sehingga dapat segera diperoleh solusi yang tepat.

Pentingnya minat belajar tiap siswa agar mampu belajar dengan baik, karena prestasi belajar juga dapat ditentukan dengan minat Itu sendiri. Minat juga berperan untuk mendorong siswa agar lebih giat dan tekun demi menghindari kegagalan serta berusaha mencapai kesuksesan (Rajab dkk., 2018).Berdasarkan hasil penelitian Hikmah (2020) menyatakan bahwa media pembelajaran power point dapat menarik minat belajar siswa sehingga mendapatkan hasil yang memuaskan, sehingga ketika hasil belajar siswa memuaskan maka media pembelajaran yang berupa power point efektif digunakan oleh guru ketika pembelajaran Jarak Jauh. Penggunaan Google classroom akan membuat pembelajaran menjadi lebih efektif terlebih lagi peserta didik bisa setiap saat bertatap muka melalui kelas online Google classroom. Dan juga peserta didik nantinya dapat belajar, menyimak, membaca, mengirim tugas, dari jarak jauh tanpa ada tatap muka langsung" (Hayami, 2018)

Adapun permasalahan dalam penelitian ini adalah apakah media powerpoint melalui classroom dapat meningkatkan motivasi belajar siswa di tengah pandemic Covid- 19 Berdasarkan masalah penelitian yang telah dirumuskan, maka tujuan utama penelitian ini 
adalah untuk mengetahui apakah media powerpoint melalui classroom dapat menjadi media pembelajaran daring yang efektif di tengah pandemic Covid- 19.

\section{METODE PENELITIAN}

Penelitian pada artikel ini merupakan penelitian kualitatif yang dilakukan dengan menjelaskan dan menganalisis fenomena, peristiwa yang terjadi saat ini atau yang sudah terjadi di masa lampau. dengan tehnik analisis menggunakan kajian kepustakaan (library research). Menurut Sugiyono (2012), mengemukakan bahwa studi kepustakaan merupakan kajian teoritis, referensi serta literatur ilmiah lainnya yang berkaitan dengan budaya, nilai dan norma yang berkembang pada situasi social dari masalah yang menjadi obyek penelitian. Buku-buku, litertur-literatur, catatan-catatan, dan laporan-laporan yang ada hubungannya dengan masalah dalam penelitian di jadikan sebagai dasar dalam menelaah dan menganalisis permasalahan dengan mempelajari dan membacanya untuk memperoleh jawaban dari tujuan penulisan artikel. Dari hasil telaah dan pembahasan melalui data yang di peroleh oleh peneliti di gunakan untuk mengidentifikasi masalah meningkatnya motivasi belajar menggunakan powerpoint melalui classroom di tengah pandemic.Meningkatnya motivasi belajar dilihat dari respon dan antusias siswa dalam mengikuti pembelajaran.

\section{HASIL DAN PEMBAHASAN}

Hasil

Berdasarkan hasil pencarian studi literatur didapatkan 10 Artikel . Artikel atau Jurnal Penelitian tersebut mengidentifikasi penggunaan google classroom untuk meningkatkan motivasi belajar.

Tabel 1. Analisis Google classroom untuk meningkatkan motivasi belajar

\begin{tabular}{|c|c|c|c|c|}
\hline No & Nama Penulis & Judul Penelitian & $\begin{array}{c}\text { Metode } \\
\text { Penelitian }\end{array}$ & Instrumet \\
\hline 1 & $\begin{array}{l}\text { Nova Elia } \\
\text { Silaen1, Anil } \\
\text { Hakim } \\
\text { Syofra2 }\end{array}$ & $\begin{array}{l}\text { Google Classroom Dalam } \\
\text { Pembelajaran Matematika Di } \\
\text { Tengah Masa Pandemi Corona Virus } \\
\text { Disease ( COVID }-19 \text { ) }\end{array}$ & $\begin{array}{l}\text { Study } \\
\text { Literatur }\end{array}$ & $\begin{array}{l}\text { Observasi } \\
\text { dan } \\
\text { dokumentasi }\end{array}$ \\
\hline 2 & $\begin{array}{l}\text { Rini Atikah\#1 } \\
\text {, Rani Titik } \\
\text { Prihatin\#2, } \\
\text { Herni } \\
\text { hernayati\#3, } \\
\text { Jajang } \\
\text { Misbah\#4 }\end{array}$ & $\begin{array}{l}\text { Pemanfaatan Google Classroom } \\
\text { Sebagai Media Pembelajaran Di } \\
\text { Masa Pandemi Covid-19 }\end{array}$ & $\begin{array}{l}\text { Study } \\
\text { Literatur }\end{array}$ & Wawancara \\
\hline 3 & $\begin{array}{l}\text { Hisyam Surya } \\
\text { Su'uga, Euis } \\
\text { Ismayati, } \\
\text { Achmad Imam } \\
\text { Agung, Tri } \\
\text { Rijanto }\end{array}$ & $\begin{array}{l}\text { Median E-Learning Berbasis Google } \\
\text { Classroom Untuk Meningkatkan } \\
\text { Hasil Belajar Siswa SMK }\end{array}$ & $\begin{array}{l}\text { Literatur } \\
\text { review }\end{array}$ & $\begin{array}{l}\text { penelusuran } \\
\text { artikel-artikel } \\
\text { penelitian } \\
\text { ilmiah dari } \\
\text { tahun } 2016 \text { - } \\
2020 \text { dengan } \\
\text { menggunakan } \\
\text { database } \\
\text { google } \\
\text { schoolar }\end{array}$ \\
\hline 4 & $\begin{array}{l}\text { Burhanudin } \\
\text { Karim, Nur } \\
\text { Kholis, }\end{array}$ & $\begin{array}{llr}\text { Keefektifan } & \text { Penggunaan Google } \\
\text { Classroom } & \text { Dalam Menunjang } \\
\text { Pembelajaran Jarak Jauh ( Study } \\
\text { Literatur) }\end{array}$ & $\begin{array}{l}\text { Study } \\
\text { Literatur }\end{array}$ & $\begin{array}{l}\text { Analisis } \\
\text { beberapa } \\
\text { artikel }\end{array}$ \\
\hline
\end{tabular}


Vol. 1 No. 2 Agustus 2021, e-ISSN : 2797-0140 | p-ISSN : 2797-0590

\begin{tabular}{|c|c|c|c|c|}
\hline & $\begin{array}{l}\text { Munoto, Euis } \\
\text { Ismayati }\end{array}$ & & & \\
\hline 5 & $\begin{array}{l}\text { Idad Suhada1, } \\
\text { Tuti Kurniati2 } \\
, \quad \text { Ading } \\
\text { Pramadi3 , } \\
\text { Milla } \\
\text { Listiawati4 }\end{array}$ & $\begin{array}{l}\text { Pembelajaran Daring } \\
\text { Google Classroom } \\
\text { Pendidikan Biologi } \\
\text { Pada } \\
\text { Wabah Covisis } 19\end{array}$ & $\begin{array}{l}\text { Penelitian } \\
\text { Diskripsi } \\
\text { kualitatif }\end{array}$ & $\begin{array}{l}\text { Tehnik } \\
\text { survey }\end{array}$ \\
\hline 6 & $\begin{array}{l}\text { Nirfayanti } \\
1 \\
\text { Nurbaeti } \\
2\end{array}$ & $\begin{array}{l}\text { Pengaruh Media Pembelajaran } \\
\text { Google Classroom Dalam } \\
\text { Pembelajaran Analisis real Terhadap } \\
\text { Motivasi Belajar Mahasiswa }\end{array}$ & $\begin{array}{l}\text { Penelitian } \\
\text { Diskripsi }\end{array}$ & $\begin{array}{l}\text { Tes hasil } \\
\text { belajar } \\
\text { Mahasiswa } \\
\text { Dan lembar } \\
\text { angket } \\
\text { motivasi } \\
\text { belajar } \\
\text { Mahasiswa }\end{array}$ \\
\hline 7 & Ari Sudibjo & $\begin{array}{l}\text { Penggunaan Media Pembelajaran } \\
\text { IPA Berbasis Google Classroom } \\
\text { Pada Materi Alat Optik Untuk } \\
\text { Meningkatkan Respons Motivasi } \\
\text { DanHasil Belajar Siswa Di SMP } \\
\text { Negeri } 4 \text { Surabaya }\end{array}$ & $\begin{array}{l}\text { Metode } \\
\text { deskriptif } \\
\text { kualtatif }\end{array}$ & $\begin{array}{l}\text { Lembar } \\
\text { validasi } \\
\text { media, } \\
\text { Lembar } \\
\text { angket siswa, } \\
\text { Lembar } \\
\text { penilaian } \\
\text { hasil belajar } \\
\text { siswa }\end{array}$ \\
\hline 8 & $\begin{array}{l}\text { Yuanita } \\
\text { Aritantia, } \\
\text { Supari } \\
\text { Muslim, } \\
\text { Theodorus } \\
\text { Wiyanto } \\
\text { Wibowo, Tri } \\
\text { Rijanto, } \\
\text { Mochamad } \\
\text { Cholik }\end{array}$ & $\begin{array}{l}\text { Kajian Literatur Sistematis Blended } \\
\text { Learning Dalam Meningkatkan } \\
\text { Motivasi Dan Hasil Belajar Siswa } \\
\text { SMK }\end{array}$ & $\begin{array}{l}\text { Sistematik } \\
\text { literatur } \\
\text { review }\end{array}$ & $\begin{array}{l}\text { Eric, Google } \\
\text { Scholar, dan } \\
\text { Science } \\
\text { Direct } \\
\text { menggunakan } \\
\text { Bahasa } \\
\text { Indonesia dan } \\
\text { Bahasa } \\
\text { Inggris pada } \\
\text { tahun } 2011 \text { - } \\
2021 \text { sesuai } \\
\text { sub-bab } \\
\text { kriteria } \\
\text { pemilihan } \\
\text { dan } \\
\text { penolakan. }\end{array}$ \\
\hline 9 & $\begin{array}{l}\text { M Fardant Al- } \\
\text { Fikri1, } \\
\text { Muhammad } \\
\text { Hanif2, } \\
\text { Mutiara Sari } \\
\text { Dewi3 }\end{array}$ & $\begin{array}{l}\text { Pelaksanaan Pembelajaran PAI } \\
\text { mengunakan Google Classroom } \\
\text { pada Masa Pandemi Covid - } 19 \\
\text { Untuk Meningkatkan Motivasi } \\
\text { Belajar Di SMP N } 2 \text { Turen }\end{array}$ & $\begin{array}{l}\text { Pendekatan } \\
\text { Kualitatif }\end{array}$ & $\begin{array}{l}\text { observasi, } \\
\text { wawancara } \\
\text { dan } \\
\text { dokumentasi }\end{array}$ \\
\hline 10 & Pattimura, SC & $\begin{array}{l}\text { Peranan Strategi Pembelajaran } \\
\text { Flipped Classroom Terhadap } \\
\text { Motivasi Dan Hasil Belajar } \\
\text { Matematika Siswa Di SMA Negeri } \\
15 \text { Pekanbaru }\end{array}$ & Studi literatur & $\begin{array}{l}\text { Pengumpulan } \\
\text { data studi } \\
\text { literatur } \\
\text { jurnal } \\
\text { penelitian }\end{array}$ \\
\hline
\end{tabular}




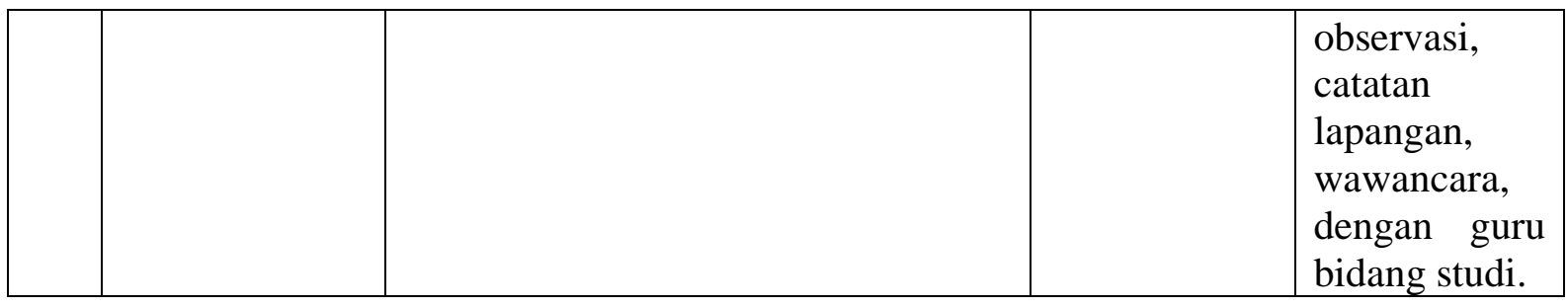

Tabel 1 menunjukkan 10 artikel yang memberikan gambaran terkait penggunaan google classroom untuk meningkatkan motivasi belajar. Pada penelitian Nova Elia Silaen1, Anil Hakim Syofra2 ( 2020 ) tentang Google Classroom Dalam Pembelajaran Matematika Di Tengah Masa Pandemi Corona Virus Disease ( COVID-19 ), menyatakan bahwa Platform Google Classroom sangat mempermudah guru, layanan pendidikan dan peserta didik dalam proses pembelajaran yang mudah dan terkonsep. Dilihat dari sisi penggunaan, platform google classroom dapat digunakan secara mudah terhadap guru dan peserta didik yang digunakan dimanapun tanpa terikat batas waktu.Selain itu Platform Google Classroom sebagai wadah diskusi yang aktif antara guru dan peserta didik. Adapun syarat mutlak dari platform ini adalah Google Classroom sebagai salah satu platform yang dapat membantu guru dalam pembelajaran jarak jauh, sehingga proses pembelajaran dapat berjalan efektif.

Pada Penelitian ( Rini Atikah , Rani Titik Prihatin , Herni hernayati , Jajang Misbah ,2021 ) Keterkaitan Pemanfaatan Google Classroom Sebagai Media Pembelajaran Di Masa Pandemi Covid-19. Keberhasilan pembelajaran dalam suatu mata kuliah ditentukan beberapa aspek diantaranya adalah guru / pendidik mampu merancang dan merencanakan strategi, media, metode dan bahan ajar guna tercapainya suatu pembelajaran yang interaktif dan komunikatif. Google Classroom memungkinkan kegiatan belajar mengajar menjadi lebih produktif dan bermakna dengan menyederhanakan tugas, meningkatkan kolaborasi, dan membina komunikasi. Pengajar dapat membuat kelas, memberikan tugas, mengirim masukan, dan melihat semuanya di satu tempat. Di Google Classroom, guru dapat membuat tugas untuk siswa, dan juga dapat mengumpulkan tugas dari mereka. Baik guru dan siswa dapat bekerja tanpa menggunakan kertas dalam aplikasi ini. proses pembelajaran terlaksana dengan baik menggunakan Google classroom. Hal ini dikarenakan pembelajaran daring melalui Google classroom pada kegiatan pembelajaran dapat dengan mudah diakses baik oleh guru / pendidik maupun siswa sesuai dengan kebutuhan kegiatan pembelajaran. Persepsi siswa mengenai mata pelajaran yang dilakukan melalui daring menggunakan aplikasi Google classroom yaitu siswa merasa senang menggunakan Google classroom karena mudah dan guru / pendidik tidak memberatkan dengan memberikan banyak tugas, Google classroom bersifat fleksibel yaitu mudah di akses dimana saja dan kapan saja, terkendala akses internet dari tidak adanya jaringan data maupun smartphone yang digunakan sebagai pendukung semua siswa untuk pelaksanaan pembelajaran e-learning. Penggunaan aplikasi Google classroom pada mata pelajaran terbukti efektif karena dapat meningkatkan hasil belajar siswa melalui perencanaan, proses, hasil dan evaluasi belajar siswa.

Hasil Penelitian ( Hisyam Surya Su'uga, Euis Ismayati, Achmad Imam Agung, Tri Rijanto, 2020 ) terkait dengan Median E-Learning Berbasis Google Classroom Untuk Meningkatkan Hasil Belajar Siswa SMK, dikemukakan bahwa selama menggunakan Google Classroom nilai rata-rata kelas mengalami peningkatan nilai rata-rata kelas sebesar 12,6-18,8. Sehingga dapat dipastikan bahwa media google classroom dapat meningkatkan hasil belajar peserta didik. Sementara penelitian dari ( Burhanudin Karim, Nur Kholis, Munoto , Euis Ismayati ) terkait dengan Keefektifan Penggunaan Google Classroom Dalam Menunjang Pembelajaran Jarak Jauh. Dari beberapa kajian literatur oleh beberapa peneliti yang diperkuat dengan beberapa artikel internasional yang menjelaskan tentang penggunaan google classroom salah satunya penelitian oleh Vanteyen et al (2017) menyimpulkan bahwa penggunaan google classroom memiliki peran besar dalam proses pembelajaran lebih muda. Dari penelitiannya tersebut juga menjelaskan google classroom memiliki keunggulan dalam pemahaman, daya 


\section{EDUTECH : Jurnal Inovasi Pendidikan Berbantuan Teknologi \\ Vol. 1 No. 2 Agustus 2021, e-ISSN : 2797-0140 | p-ISSN : 2797-0590}

tarik dan mudah dioperasikan dan sangat cocok digunakan dalam pembelajaran jarak jauh. Penggunaan google classroom memberikan peluang lebih dalam proses pembelajaran dalam mengembangkan skill profesionalnya dan cocok dalam menerapkan keterampilan abad 21, baik itu dalam prespektif guru maupun peserta didik. Heggart \& Yoo (2018) juga menyimpulkan bahwa penggunaan google classroom dapat meningkatkan partisipasi siswa sehingga meningkatkan nilai siswa. Hal tersebut yang dapat dijadikan acuan untuk menggunakan google classroom dalam kondisi pandemi saat ini yang mengharuskan siswa belajar dari rumah tetapi juga harus mendapatkan partisipasi yang cukup baik. Penelitian ( Idad Suhada1 , Tuti Kurniati2 , Ading Pramadi3 , Milla Listiawati4 ) dari beberapa peneliti menjelaskan dari hasil pembelajaran daring berbasis google classroom pada mahasiswa pendidikan biologi pada masa wabah covid-19 dapat disimpulkan bahwa penggunaan aplikasi google classroom dalam pembelajaran daring pada masa wabah covid-19 sudah cukup baik dan efektif, hanya saja akan lebih baik jika dipadukan dengan platform online lainnya. Dari penelitian ( Nirfayanti1, Nurbaeti 2 ) berkaitan dengan Media Pembelajaran Google Classroom Dalam Pembelajaran Analisis Real Terhadap Motivasi Belajar Mahasiswa dikemukakan bahwa terdapat pengaruh signifikan antara media pembelajaran google classroom terhadap motivasi belajar mahasiswa Semester V Program Studi Pendidikan Matematika FKIP Universitas Muslim Maros. Yang ditunjukkan dengan nilai statistik uji hipotesis yang diperoleh. Penelitian dari ( Ari Sudibjo,2019 ) berkaitan dengan Penggunaan Media Pembelajaran IPA Berbasis Google Classroom Pada Materi Alat Optik Untuk Meningkatkan Respons Motivasi Dan Hasil Belajar Siswa Di SMP Negeri 4 Surabaya, berdasarkan hasil analisis dan pembahasan data penelitian yang telah dilakukan oleh peneliti, dapat disimpulkan bahwa Penggunaan media pembelajaran IPA berbasis Google Classroom pada materi pokok Alat Optik, sangat kuat dikatakan layak untuk digunakan dalam pembelajaran IPA dan membuat siswa termotivasi kuat untuk belajar IPA dengan melihat presentase indikator respons setuju sebesar $70 \%$. Selain itu dapat membantu siswa untuk meningkatkan hasil belajar siswa dalam aspek kognitif.

Penelitian dari ( Yuanita Aritantia, Supari Muslim, Theodorus Wiyanto Wibowo, Tri Rijanto, Mochamad Cholik, 2021 ) Berdasarkan metode penelitian sistematik literatur review dari berbagai jurnal yang berhubungan dengan pengaruh model blended learning pada siswa SMK, maka dapat disimpulkan bahwa model blended learning dapat memberikan peningkatkan terhadap motivasi belajar dan hasil belajar. Ketika motivasi belajar meningkat maka siswa dengan senang dan tanpa ada paksaan akan belajar yang mengakibatkan hasil belajar ikut meningkat. Penggunaan media online e learning Edmodo, LMS Moodle, Google Classroom ketika pelaksanaan model blended learning menghasilkan hasil yang sama yaitu peningkatan rata-rata hasil belajar dan motivasi belajar siswa. Namun, Google classroom memiliki kelebihan karena setiap siswa biasanya telah memiliki akun gmail yang memudahkan untuk sign in. Kemudian terdapat fitur google meet yang dapat digunakan untuk melakukan sesi meeting online. Format yang digunakan untuk di upload ke dalam suatu e learning sebaiknya terdiri dari file presentasi power point, file audio, file video presentasi sehingga pembelajaran tidak monoton karena mengaktifkan indera penglihatan maupun pendengaran. Dari penelitian (M Fardant Al-Fikri1, Muhammad Hanif2, Mutiara Sari Dewi3, 2021 ) berkaitan tentang pelaksanaan pembelajaran pai dengan menggunakan google classroom pada masa pandemi covid-19 untuk meningkatkan motivasi belajar siswa di SMP N 2 Turen dapat disimpulkan bahwa Google Classroom sebagai media utama pembelajaran pada saat pandemi Covid-19 ini paling berpengaruh untuk meningkatkan motivasi belajar siswa di SMPN 2 Turen. Aplikasi Google Classroom juga masih sangat layak digunakan sebagai media pembelajaran di sekolah pada saat pandemi ini karena penggunaan Google Classroom dalam proses pembelajaran dapat membangkitkan semangat belajar dan juga keinginan dan daya tarik sebagai motivasi belajar siswa, selain itu Google Classroom juga bisa membantu siswa untuk mempermudah pemahaman terhadap materi pelajaran yang telah disampaikan. Penelitian dari ( Pattimura, SC,2018 ) mengemukan bahwa dari review berbagai jurnal berdasarkan analisis dan hasil pembahasan yang telah di ungkap pada bab sebelumnya dapat disimpulkan bahwa adanya 
dalam Dian lestari dkk peningkatan motivasi dan hasil belajar matematika melalui penerapan strategi pembelajaran flipped classroom. Hal ini dapat dilihat dari beberapa perilaku dari beberapa indikator antara lain, siswa antusias dalam menyanggah dan menyetujui pertanyaan guru. Siswa antusias dalam mengerjakan soal yang diberikan guru. Siswa antusias dalam mengajukan dan menjawab pertanyaan dari guru.

\section{Pembahasan}

Pembelajaran daring merupakan tehnik pengganti pembelajaran yang dilakukan dalam kelas ketika pembelajaran di kelas sudah tidak memungkinkan di lakukan ( Abdul Rohman, 2021). Banyak aplikasi yang dapat di gunakan untuk melakukan kegiatan pembelajaran secara daring / online. Aplikasi classroom saat ini banyak di gunakan oleh lembaga pendidikan, seperti sekolah,perguruan tinggi dan lain - lain . Hal ini karena banyak keuntungan yang didapat saat menggunakan aplikasi classroom. Beberapa keuntungan classroom yaitu :

1. Aplikasi didapatkan dan digunakan dengan gratis

2. Memiliki penyimpanan data yang besar

3. Terhubung dengan aplikasi produk lain dari google seperti google drive dan google calendar

4. Terhubung dengan aplikasi youtube

5. Mudah untuk di gunakan pada PC, Laptop, maupun mobile ( smartphone )

6. Bisa di akses kapan saja dan di mana saja

7. Tidak memakan bandwidth atau data akses / kuota yang besar

8. Memfasilitasi guru untuk melakukan pengajaran dan siswa menerima materi

9. Terjalin komunikasi dua arah

10. Terdapat unsure multimedia ( teks,gambar,audio,video )

11. Dapat menambahkan jumlah guru dan siswa yang tidak terbatas.

Permasalahan yang sering terjadi di SMA Negeri 1 Candiroto dalam pembelajaran daring seperti peserta didik tidak antusias, pasif untuk membaca materi,jenuh, malas menjawab,diskusi yang kurang interaktif, pengerjaan tugas yang tertunda, dengan classroom permasalahan permasalahan tersebut dapat berkurang. Dan dapat terlihat perubahan yang signifikan tingkat permasalahan yang timbul saat sebelum dan sesudah penggunaan classroom. Sebelum penggunaan media classroom muncul jumlah kasus sebanyak 99 siswa dilihat dari keaktifan pada classroom guru mata pelajaran, absensi harian dan juga ketepatan pengumpulan tugas. Setelah penggunaan classroom menurun hanya sekitar 34 siswa yang mempunyai permasalahan seputar pembelajaran daring.

\section{KESIMPULAN}

Pembelajaran daring merupakan tehnik pengganti pembelajaran yang dilakukan dalam kelas ketika pembelajaran di kelas sudah tidak memungkinkan di lakukan, dalam hal ini menimbulkan kurangnya motivasi belajar peserta didik. Upaya yang dilakukan untuk membangkitkan motivasi peserta didik, maka guru dalam melaksanakan pembelajaran daring melakukan sebuah inovasi yaitu menggunakan media powerpoint melalui google classroom. Google Classroom sebagai salah satu jenis dari sekian banyak jenis learning management sytem yang digunakan pada pembelajaran saat ini di SMA N 1 Candiroto. Terjadi perubahan yang signifikan dalam mengatasi tingkat permasalahan yang timbul saat sebelum dan sesudah penggunaan classroom. Sehingga Google Classroom dapat menunjang proses berlangsungnya pembelajaran jarak jauh

\section{DAFTAR PUSTAKA}

Al-Fikri,M.F., Hanif, M., Dewi, M.,S. (2021). Pelaksanaan Pembelajaran PAI mengunakan Google Classroom pada Masa Pandemi Covid - 19 Untuk Meningkatkan Motivasi Belajar Di SMP N 2 Turen. Vicratina: Jurnal Pendidikan Islam Volume 6 Nomor 2 Tahun 2021 
Aritantia,Y., Muslim S.,Wibowo,T.,W,Rijanto,T.,Cholik M.,(2021). Kajian Literatur Sistematis Blended Learning Dalam Meningkatkan Motivasi Dan Hasil Belajar Siswa SMK.Jinotep, 8 (2) : 178-185

A.Sudibjo, (2019). "Penggunaan Media Pembelajaran IPA Berbasis Google Classroom Pada Materi Alat Optik Untuk Meningkatkan Respons Motivasi Dan hasil Belajar Siswa Di SMP Negeri 4 Surabaya”. Jurnal Education And Development, 7(3) : 278

Atikah, R., Prihatin, R..A., Hernayati, H. \& Misbah, J. (2021). Pemanfaatan Google Classroom Sebagai Media Pembelajaran Di Masa Pandemi Covid-19. Jurnal Petik, Volume 7, No 1 , Hal 7 .

Basilaia, G, \& Kvavadze, D. (2020). Transition to Online Education in Schools during SARSCoV-2 Coronavirus (COVID-19) Pandemic in Georgia. Pedagogical Research, 5 (4). https://doi.org/10.29333/pr/7937

Bilfaqih, Y., \& Qamaruddin. M.N. (2015). Esensi Pengembangan Pembelajaran Daring. Yogyakarta : Deepublihs

Fadillah, A., \& Baist, A. (2017). Hubungan Motivasi Dan Perilaku Terhadap Hasil Belajar Mata Kuliah Matematika Ekonomi. Prima: Jurnal Pendidikan Matematika, 1(1), 43- 48. https://doi.org/10.31000/prima.v1i1.253

Gunawan.,Yeni Suranti,N.M., Fathoroni. (2020).Variations of Models and Learning Platforms for Prospective Teachers During the COVID -19 Pandemic Period. Indonesian Journal of Teacher Education, Vol. 1 No. 2, 2020: 61-70.

Harjanto,T., \& Sumunar,D.S.E.W.(2018). Tantangan dan peluang pembelajaran dalam jaringan: studi kasus implementas elok (e-learning: open for knowledge sharing) pada maha peserta didik profesi ners. Jurnal Keperawatan Respati Yogyakarta,5, 24-28.

Hikmah, S.N. \& Maksar, S. (2020). Pemanfaatan Aplikasi Microsoft Powerpoint pada Siswa SMP Kelas VII dalam Pembelajaran Koordinat Kartersius. Jurnal Ilmiah Matematika Realistik, 1(1), 15-19

Karim,B.,Kholis,N., Munoto,\& Ismayati,E. (2021). Keefektifan Penggunaan Google Classroom Dalam Menunjang Pembelajaran Jarak Jauh (Study Literatur). Jurnal Pendidikan Teknik Elektro. Volume 11 Nomor 01 Tahun 2022, 61-67.

Nirfayanti, N., \& Nurbaeti, N. (2019). Pengaruh Media Pembelajaran Google Classroom Dalam Pembelajaran Analisis Real Terhadap Motivasi Belajar Mahasiswa. Proximal: Jurnal Penelitian Matematika Dan Pendidikan Matematika, 2(1), 50-59. Retrieved from https://e-journal.my.id/proximal/article/view/211

Rajab, A., Masruhim, M. A., \& Widiyowati, I. I. (2018). Hubungan Antara Minat Belajar Dengan Hasil Belajar Siswa SMA Menggunakan Model Pembelajaran Numbered Head Together dengan Bantuan Media Papan Tempel Pada Pokok Bahasan Tata Nama Senyawa. Jurnal Zarah, Vol. 9 No. 1,1(1), 39-44.

Rohman,A. (2021). Panduan Praktis Pembelajaran Daring dengan Google Classroom dan Google Meet. Jakarta: Diterbitkan pertama kali oleh Penerbit PT Elex Media Komputindo Kelompok Gramedia, Anggota IKAPI.

Santosa, Farah Heniati, Habibi Ratu Perwira Negara, and Samsul Bahri. (2020). "Efektivitas Pembelajaran Google Classroom Terhadap Kemampuan Penalaran Matematis Siswa". Jurnal Pemikiran Dan Penelitian Pendidikan Matematika (JP3M), 3(1):62-70. doi: 10.36765/jp3m.v3i1.254.

SC, P. (2018). Peranan Strategi Pembelajaran Flipped Classroom Terhadap Motivasi Dan Hasil Belajar Matematika Siswa Di SMA Negeri 15 Pekanbaru. Jurnal Pendidikan Tambusai, 2(2), 897-905. https://doi.org/10.31004/jptam.v2i4.39

Silaen. N.E \& Syofra.A.H. (2020). Study Literatur Google Classroom Dalam Pembelajaran Matematika Di Tengah MasaPandemi Corona Virus Disease (Covid - 19).Prosiding Seminar Nasional Multidisiplin Ilmu Universitas Asahan ke-4 Tahun 2020. 
Sofyan,L. \& Rozaq, A. (2019). Pembelajaran Daring Konbinasi Berbasis Whatsapp Pada Kelas Karyawan Prodi Tehnik Informatika Universitas PGRI Madiun. Jurnal Nasional Pendidikan Teknik DOI: http://dx.doi.org/10.23887/janapati.v8i1.17204

Soni., R,Afdil H.,Hayami,E.,Fatma,Y.,Wenando, F,A., Al Amien, J., Fuad,E.,Unik, M., Mukhtar,H.,Hasanuddin. (2018). Optimalisasi pemanfaatan Google Classroom sebagai Media Pembelajaran Di SMK Negeri 1 Bangkinang. Jurnal Pengabdian Untuk Mu Negeri I, Vol.2 No.1, Mei 2018.

Sugiyono. (2012). Dasar-Dasar Evaluasi Pendidikan. Jakarta: PT Bumi Aksara.

Suhada, I., Kurniati,T., Pramadi., Ading., Listiawati, \& Milla (2020). Pembelajaran daring berbasis Google Classroom mahasiswa pendidikan biologi pada masa wabah Covid19. Digital Library UIN Sunan Gunung Djati. pp. 1-10.

Su'uga, H, S., Ismayati, E., Agung, A.,I., \& Rijanto,T. (2020). Median E-Learning Berbasis Google Classroom Untuk Meningkatkan Hasil Belajar Siswa SMK. Jurnal Pendidikan 2020

Syaripah. (2016). Pengaruh Persepsi Pembelajaran Matematika Terhadap Motivasi Belajar Siswa Dalam Bidang Matematika Di Sekolah Sma N 1 Curup Timur T.P 2015/2016. 2(2), 117-131. 